\title{
Application of shallow seismic profiling to study riverbed architectural facies: A case study of the Tocantins river (Pará - Brazil)
}

\author{
MARCO IANNIRUBERTO, JOSÉ E.G. CAMPOS and VITTO C.M. ARAÚJO
}

Universidade de Brasília, Instituto de Geociências, Campus Universitário Darcy Ribeiro 71900-000 Brasília, DF, Brasil

Manuscript received on March 9, 2010; accepted for publication on March 22, 2011

\begin{abstract}
To date, the vast majority of river sedimentology study has relied on two main categories of observation: direct observation of shallow trenches, cut faces and cores or geophysical survey on dry and shallow regions of braid bars. In this study, a sub-bottom profiler was used to investigate the stratigraphy of the lower course of the Tocantins River in the Amazon region, between the city of Tucuruì and the village of Nazaré dos Patos. The interest in this specific region lies on the possible variation of the fluvial regime due to the installation of the dam of the Tucurui hydroelectric plant and the perspective that such river would become navigable as soon as the canal lock will be completed. Collected data show a detailed variety and complexity of architectural elements, as well as internal structure of sandy macroforms. Furthermore, the results allowed the identification of three main environments linked to channel sedimentation processes: by-pass, transition and deposition environments, whose distribution is linked to channel dynamics and bedrock topography. The application of the study is manifold, once it provides not only an insight into sedimentary structure of alluvial forms and sedimentation history, but also elements demanded to plan eventual engineering works for river navigability.
\end{abstract}

Key words: anastomosed rivers, alluvial sedimentology, architectural facies, stratigraphy, high-resolution seismic.

\section{INTRODUCTION}

The Tocantins-Araguaia is the largest watershed totally included in the Brazilian territory, draining a total area of $757,000 \mathrm{~km}^{2}$, corresponding to $9 \%$ of the country (Lima et al. 2004, Latrubesse et al. 2005). The Tocantins River has about 2,400 km length, with its main tributaries related to the Manoel Alves, do Sono, Manoel Alves da Natividade, Araguaia, Santa Teresa and Itacaiunas rivers with an average discharge of $11,800 \mathrm{~m}^{3} / \mathrm{s}$ (Lima et al. 2004).

The Tocantins-Araguaia basin plays an important economic role by being a region with relevant potential for agriculture, mining and

Correspondence to: Marco Ianniruberto

E-mail: ianniruberto@unb.br hydroelectric energy production. This latter sector is particularly important, as the 6 most important hydroelectric plants installed along the river (Serra da Mesa, Cana Brava, São Salvador, Peixe Angical, Luís Eduardo Magalhães and Tucuruí) account for $15 \%$ of the hydroelectric production of Brazil (ANEEL 2010).

Based on a study of Potter (1978), Gupta (2007) synthesized the following parameters to define a big river: length $>10^{3} \mathrm{~km}$, drainage basin area $>$ $10 \mathrm{~km}$, water discharge $>200 \times 10^{9} \mathrm{~m}^{3} /$ year and sediment load up to $1000 \mathrm{Mt} / \mathrm{year}$. According to this definition, the Tocantins River should be included in such category, although suspended sediment load is comparatively small due to the fact that the river 
drains mostly cratonic areas in savanna and lies in a wet tropical climate region (Latrubesse et al. 2005).

Recent study of Sambrook Smith et al. (2009) described the sedimentological and alluvial architecture of a large braid bar in the Paraná River and pointed to the few sedimentological data available for large rivers due to the logistic difficulty of monitoring such channels.

To date, the vast majority of river sedimentology study has relied on two main categories of observation: shallow trenches, cut faces and cores, or the application of shallow geophysical methods on dry and shallow regions of braid bars. A variety of geophysical methods have been applied to study fluvial environments, providing the description of different characteristics and physical parameters.

Baines et al. (2002) showed the applicability of ERI (Electrical Resistivity Imaging) to map the geometry of gravel and sand river channel-fills buried in an environment where GPR penetration was hampered by the presence of clay and silt. Hirsch et al. (2008) carried out a comparison among different geophysical methods and observed that while ERI was capable of detecting changes in sediment types and boundaries, GPR (Ground Penetrating Radar) showed the internal structure of a river terrace site, and this capability was used in many studies of alluvial river deposits (Sambrook Smith et al. 2006, Hugenholtz et al. 2007, Sambrook Smith et al. 2009). On the other hand, high-resolution seismic is a well established methodology to study internal sedimentary facies in a variety of environments (eg: Hofmann et al. 2006, Novak and Bjorck 2002).

Such methods allowed the study of morphological facies and the internal structure of sand bars and dunes in both marine and fluvial environments in order to describe recent and ancient depositional sequences, as well as to gather data for sedimentological modelling.

In this study, a sub-bottom profiler was used to investigate stratigraphy of the lower course of the Tocantins River, in the Amazon region, between the city of Tucuruí and the village of Nazaré dos Patos. The interest in this specific region lies on the possible variation of the fluvial regime due to the installation of the dam of the Tucuruí hydroelectric plant and the perspective that such river would become navigable as soon as the canal lock will be completed.

In most cases the construction of a dam implies in a reduction of the liquid discharge, as a consequence of storage and evaporation losses, as well as the capacity of sediment transport (Brandt 2000). In terms of sediment discharge, Williams and Wolman (1984 apud Brandt 2000) estimated the sediment retention efficiency for large reservoirs to be greater than $99 \%$ for the bed load as a result the transport capacity of a flow downstream of a dam is larger than the effective load.

Using the notation of Brandt (2000), where Q is the water discharge, $\mathrm{L}$ the solid load transported and $\mathrm{K}$ the transport capacity, the branch of the Tocantins River downstream the Tucuruí dam can be classified as Case 1 (reduced Q and $\mathrm{L}<\mathrm{K}$ ). In this case, an adjust in the transversal section of the canal can occur, showing the degradation of the river bed and the erosion of margins, being the equilibrium determined by the relative erodibility between the bed and margins of the river (Brandt 2000). The length of the branch affected by degradation also depends on these factors, as well as the sediment transport of the tributaries downstream the dam.

In the study area it is possible to recognize the first stretch downstream the dam (Fig. 1), with about $18 \mathrm{~km}$ length, as a straight type, while further downstream the river becomes anastomosed, with increasing sinuosity downstream the dam.

Regarding the hydrossedimentological characterization, according to Lima et al. (2004) this stretch of the Tocantins River shows low suspended sediment concentration and discharge. Based on measurements taken at the Tucuruí station from 1981 to 1998 , the mentioned author reports mean values of $9 \mathrm{mg} / \mathrm{L}$ for sediment concentration and 8.388 tons/day for suspended sediment discharge. 

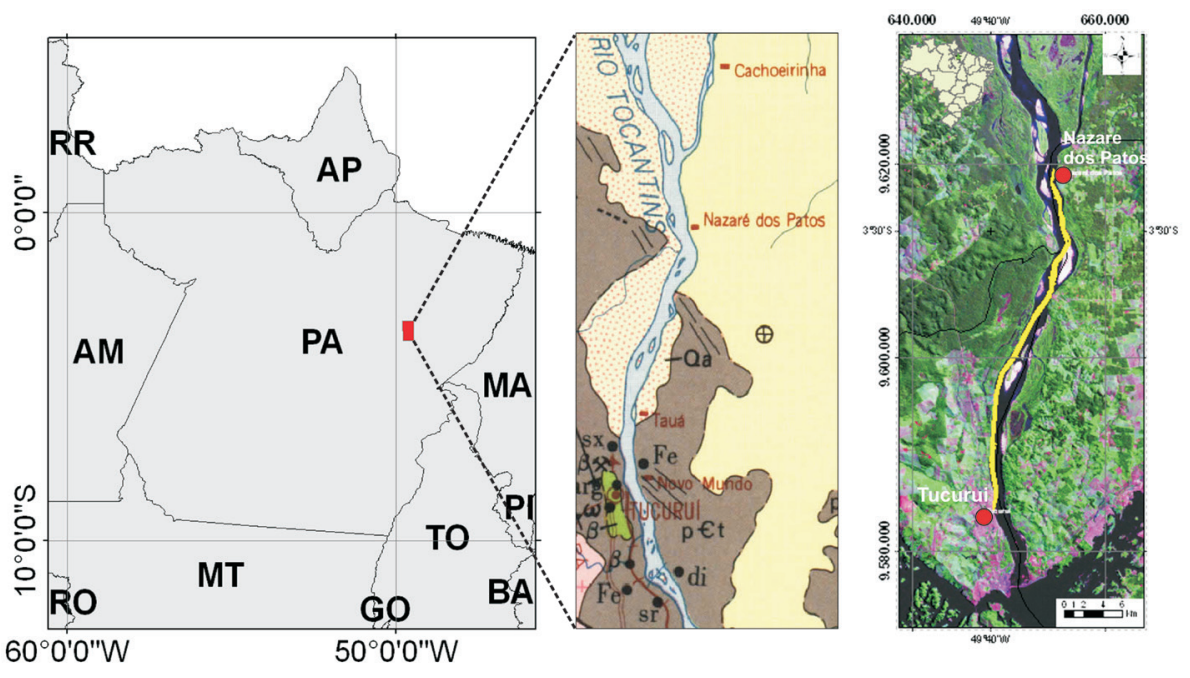

Figure 1 - Location map of the study area. Center image: Geologic map from RadamBrasil Project (Brasil 1974), prior to dam construction. Right image: LANDSAT ETM+, color mosaic, 224-62 and 224-63 (2001); the center line corresponds to the navigation track.

It is worth mentioning that the same parameters measured at the Itupiranga station, upstream the reservoir, are $48 \mathrm{mg} / \mathrm{L}$ and 46.737 tons/ day, respectively. The difference between the two stations is explained by the retention of the suspended sediment load in the reservoir basin.

Such low values of suspended sediment load downstream the dam lead to think that in this part of the river the sedimentation process is largely determined by bed load, being the dissolved load of minor importance in the Brazilian rivers (Christofoletti 1981).

On the other hand, downstream the dam, the decrease of the suspended load turns the waters into "sediment starved", with the consequent erosion of margins and the river bed until the local sediment production balances the transport potential of the flow (Williams and Wolman 1984).

On such basis, it is possible to infer that the features detected in the seismic survey must be associated to the period before the closing of the dam or originated from the erosion and re-mobilization of river bed forms downstream the dam.

The aim of this work is to describe acoustic and architectural facies of the river bed, associated to sediment transport and deposition mechanisms, considering the impact of such factors on the installation of a waterway.

\section{Geological SETtings}

The study area is located in the center-north portion of Pará State, at the occidental margin of the Parnaíba Basin. The geological framework includes the basement of the Parnaíba Basin, as well as the Cainozoic successions related to the Barreiras Group and the alluvium of the Tocantins River.

According to Barbosa et al. (1966) and Rezende (1998), the area corresponds to a transition region between the crystalline basement - Xingu Complex, situated in the left margin of the river, and a volcanicsedimentary sequence with low metamorphic grade related to the Tucuruí Formation. The Paleogene deposits, as well as quaternary sediments, compose the alluvium. Table I shows the synthesis of the stratigraphy of the study region.

\section{MATERIALS AND METHODS}

The shallow seismic method was adopted to survey the area using a high resolution seismic profiler interfaced with a WADGPS (Wide Area 
TABLE I

Stratigraphy synthesis of the central region of Pará State, Brazil.

\begin{tabular}{|c|c|c|}
\hline $\begin{array}{c}\text { Lithostratigraphic } \\
\text { units }\end{array}$ & Chronostratigraphy & $\begin{array}{c}\text { Main } \\
\text { Lithotypes }\end{array}$ \\
\hline $\begin{array}{c}\text { TUCUNARÉ } \\
\text { GROUP }\end{array}$ & QUATERNARY & $\begin{array}{c}\text { Unconsolidated } \\
\text { sand }\end{array}$ \\
\hline $\begin{array}{c}\text { BARREIRAS } \\
\text { GROUP }\end{array}$ & PALEOCENE & $\begin{array}{c}\text { Sandstone, } \\
\text { graywacke and } \\
\text { conglomerate }\end{array}$ \\
\hline $\begin{array}{c}\text { VOLCANO- } \\
\text { SEDIMENTARY }\end{array}$ & NEOPROTEROZOIC & $\begin{array}{c}\text { Schists and } \\
\text { amphibolites }\end{array}$ \\
\hline $\begin{array}{c}\text { TOCANTINS } \\
\text { FOUP TUCURUÍ }\end{array}$ & MESOPROTEROZOIC & $\begin{array}{c}\text { Metabasalts, } \\
\text { schists and } \\
\text { amphibolites }\end{array}$ \\
\hline XINGU & ARCHEAN / & $\begin{array}{c}\text { Gneisses e } \\
\text { migmatites }\end{array}$ \\
\hline COMPLEX & PALEOPROTEROZOIC & \\
\hline
\end{tabular}

Differential GPS) receiver and navigation suite. The WADGPS is a satellite broadcast technique of GPS differential corrections that allows attaining sub-meter accuracy

The Edgetech 3100P sub-bottom profiler, equipped with the tow-vehicle SB-216, was operated with a "chirp" pulse of bandwidth $2-15 \mathrm{kHz}$, and achieved a penetration up to $10 \mathrm{~m}$ in sandy bottom, with about $10 \mathrm{~cm}$ resolution.

Accurate positioning was obtained by using the DGPS receiver Trimble DSM 232 with the satellite differential correction Omnistar HP, attaining accuracy of about $20 \mathrm{~cm}$ on average.

Positioning and seismic systems were interfaced via Hypack navigation software, which allowed real time referencing of the seismic profiles, as well as the survey planning and the on-line navigation.

The survey was carried out along navigation lines parallel to the river canal (thalweg), and some transversal lines were run to verify the crosscontinuity of sedimentary structures.

More than $120 \mathrm{~km}$ of seismic lines were acquired in a stretch of about $40 \mathrm{~km}$ between the city of Tucuruí and the village of Nazaré dos Patos.

\section{SEISMIC RECORDS DESCRIPTION}

The high-resolution seismic profiles show two principal units. The top of Unit 1 is a strong and continuous reflector (Fig. 2-a), interpreted as the acoustic basement (bedrock). The surface of such unit shows an evident roughness (Fig. 2-b), which influences the turbulence of the flow and the transport of the bed load. The outcrops indicate erosion areas or sediment by-pass. Topographical depressions of the exposed basement can cause sediment retention (Fig. 2-c).

The top of Unit 2 is formed by a continuous and regular reflector, with several parallel layers (Fig. 2-e) or cross stratifications (Fig. 2-f), interpreted as top of bars composed of well-sorted layers of fine to medium sand separated by layers of coarser and poorly sorted sand. The internal reflections show parallel or sub-parallel reflections, marked by the presence of prograding clinoforms, oblique sigmoid bodies and large scale (decameters) parallel and crossed stratification, related to planes of deposition reactivation.

The contact between Unit 1 and 2 occurs in a gradual transition region (Fig. 2-d), where the width of sediments increases with the transition from the plane bed (Fig. 2-e) to transversal bars (Fig. 2-f), as a consequence of increased sediment load.

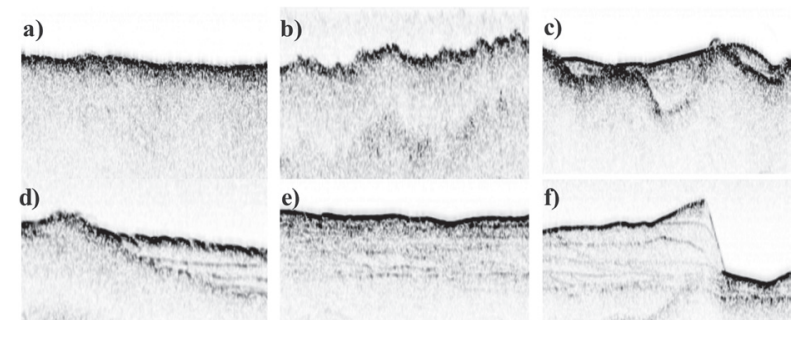

Figure 2 - Typical acoustic interfaces of Unit 1 and 2.

The seismic records clearly show the internal structure of river bars, where the variation of acoustic impedance that generates the reflections must be due to changes in the sedimentation regime associated to cyclic events. The observation of emerged and partly eroded bars along the river (Fig. 3) allowed the identification of a sediment layer poorly sorted, 


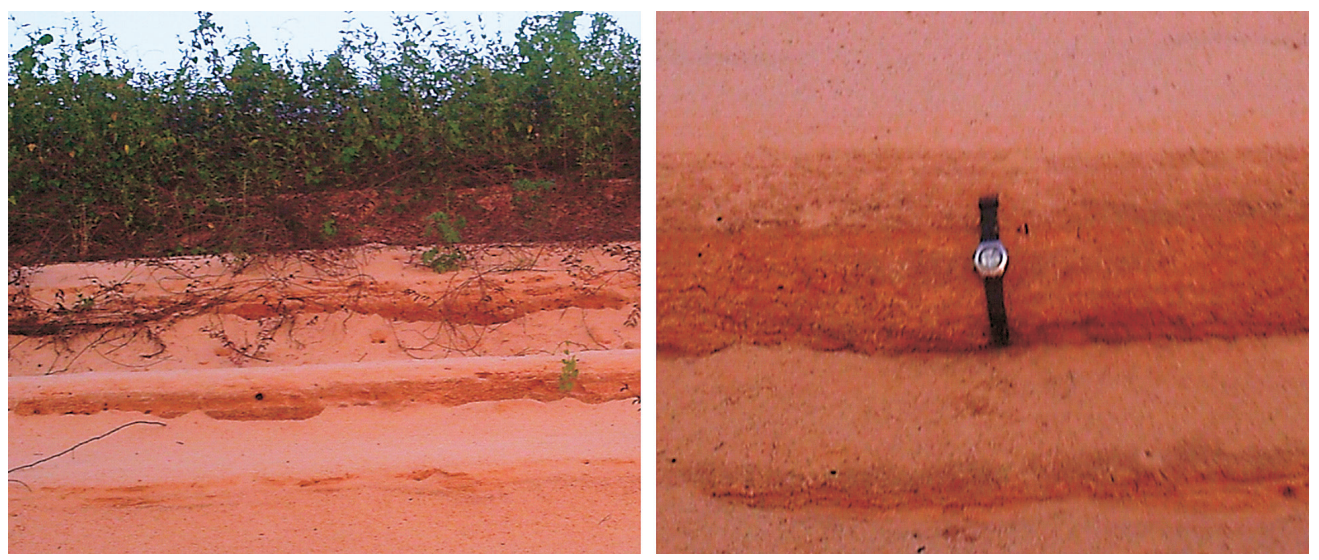

Figure 3 - Photograph of the stratification in a partly eroded sand bar on a river isle margin (left), and detail of poorly sorted sediment layer (right).

with a thickness of a few decimeters, which could be associated to extreme discharge events, flooding of the margins, erosion and deposition reactivation.

Considering that the presence of the hydroelectric reservoir has a regulatory effect on the flow and floods, it could be supposed that such events were related to the period before the reservoir configuration.

\section{Description OF SEISMIC FACIES AND ARChITECTURAL ELEMENTS}

The integration of seismic sections with the information acquired in sparse outcrops in bar cuts and beaches shows that the fluvial system is widely dominated by sand deposition. The pelitic materials (silt and clay) are certainly present in the deposition systems as a whole, but its sedimentation is limited to inundation flats, which were not included in this paper that focused the study on the active river channel.

In the surveyed portion of the active channel it was possible to detect three conditions of transportdeposition, including by-pass areas, with enhanced erosion and transport, deposition areas, with the accumulation of sand in different flow conditions, and transition areas associated to the interposition of the former ones.

As the resolution of the seismic survey only detects forms thicker than $10 \mathrm{~cm}$ and that extend for at least a few meters, the architectural elements will be described according to the fluvial facies denomination proposed by Miall $(1978,1985)$.

Along the river, downstream the Tucuruí dam, the following sand facies dominate: St (cross-stratified sandstone), Sp (planar cross-stratified sandstone), Sh (horizontally stratified or laminated sandstone) and Se (sandstone in erosional channel). Regarding the architectural elements, the following bed forms are observed: sandy bed-forms (SB), channel element $(\mathrm{CH})$, downstream accretion element (DA), lateral accretion (LA) and laminated sand sheets (LS).

It is worth mentioning that, as distinct bedforms are strictly linked to the paleo-topography of the bedrock, and according to the observation of seismic profiles where the bedrock is detectable, beds of dunes and bars are associated to an irregular bedrock topography.

Examples of seismic profiles in different contexts, with the respective description of facies and sedimentary processes are described below. Both vertical and horizontal scales on profiles are in meters.

\section{By-Pass Environments}

In the by-pass environments, the erosion processes dominate the transport via mechanisms such as traction and suspension. Generally, in such environments, the bedrock is locally exposed and the depth reaches $20 \mathrm{~m}$. The by-pass environments are mostly observed in the main canals, and seldom occur 
near the margins. The main canals can occur in the central portion of the current fluvial bed, but in other cases they can result in strong asymmetries, with the thalweg displaced towards one of the margins.

Figure 4 shows an example of a by-pass environment, where the riverbed shows a rough profile, and there are no reflectors indicating sediment accumulation. In Figure 4 there is a clear tendency that highlights the inclined planes towards the North (slant dashed lines), which are interpreted as schist foliation planes or a high-density fracture system.

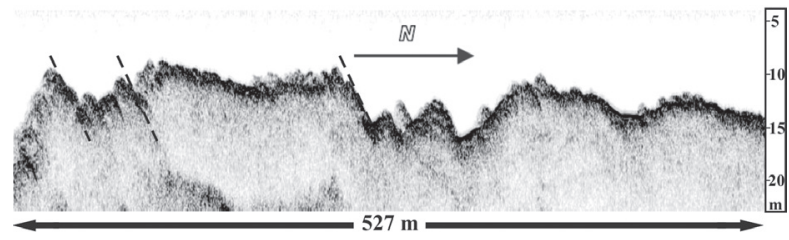

Figure 4 - Example of a seismic profile of rocky bed exhibiting likely structural trend foliation or high density fracturing (dashed lines).

Channels deeper than $10 \mathrm{~m}$ can occur locally, being interpreted as the product of a combined action of flow turbulence and current vortices. Figure 5 shows an example of such structure. It is also possible to observe the structural trend present in the bedrock. In the NNE section, at a depth slightly more than $10 \mathrm{~m}$, a small channel filled with sand can be observed.

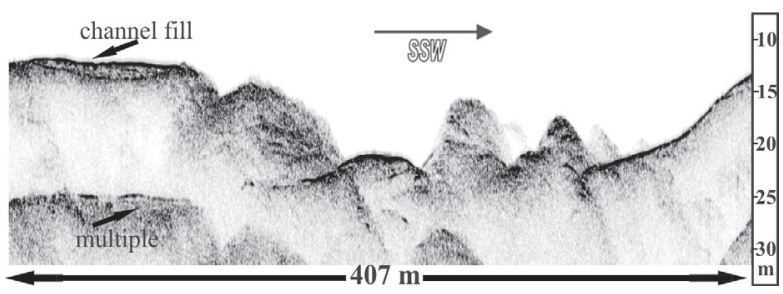

Figure 5 - Image showing a valley in a rocky outcrop due to sediment by pass in an area of large depth gradients.

When the fluvial channel becomes deeper that $20 \mathrm{~m}$, the reduced flow and transport capacity allow the beginning of deposition processes. Figure 6 shows an example of such environment where in the center of the valley occurs the filling with coarse sandy materials or the mixing of sand and silt. At the North and South of the channel, the river bed is rocky. Such feature is associated to the region of bedrock weakness (fault zone or contact of rocks with different resistance to erosion).

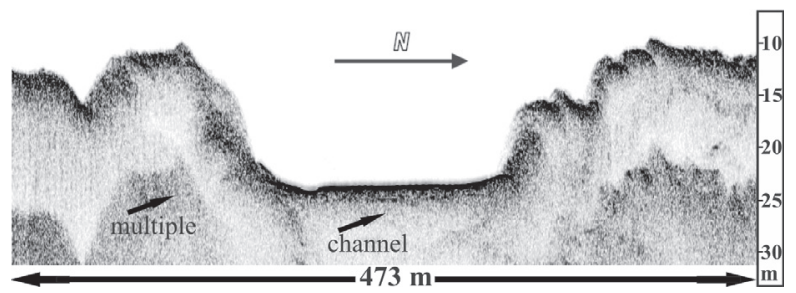

Figure 6 - Example of a partially filled wide erosion canal sculptured in the bedrock.

\section{Deposition Environments}

Figure 7 represents a series of longitudinal bars, with internal reflectors that define plane-parallel layers (dashed lines) that can be internally laminated or compose sets of cross layers of a lower order (dotted lines).

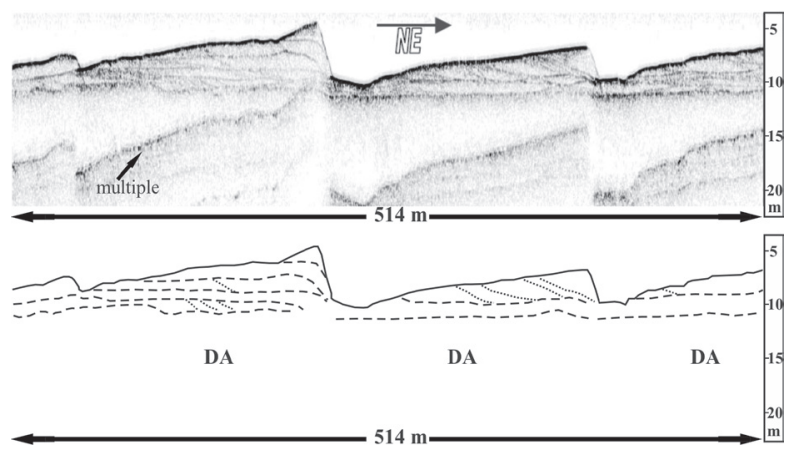

Figure 7 - Example of bar structures composing an architectural element of longitudinal accretion.

At the frontal portion of the bars the reflectors present an inclination towards the deeper part of the channel, showing the migration tendency of such macroforms, which represent the depositional areas that result in longitudinal accretion architectural elements (DA) composed of Sh, St and Sp facies type. The sedimentary process dominating the formation of the macroforms is of traction and saltation type, in which the deposition occurs because of the gradual decrease of energy.

It is interesting to observe that the bar in the center of Figure 7 (vertical exaggeration 6:1) has 
about $6 \mathrm{~m}$ height relative to the thalweg, with a slope of the slip face of about $50 \%\left(27^{\circ}\right)$.

The example in Figure 8 shows a site with thin a deposition directly above the acoustic basement (dash-dot line), which is here characterized by an irregular topography. In this case, horizontal layers (dashed lines) dominate the internal bar structure. The undulated top of the bedform (continuous line) shows a set of transversal bars, orthogonal to the main migration direction of the flow, which represent a sequence of architectural elements of lateral accretion with the migration of sandy facies due to the grain traction.

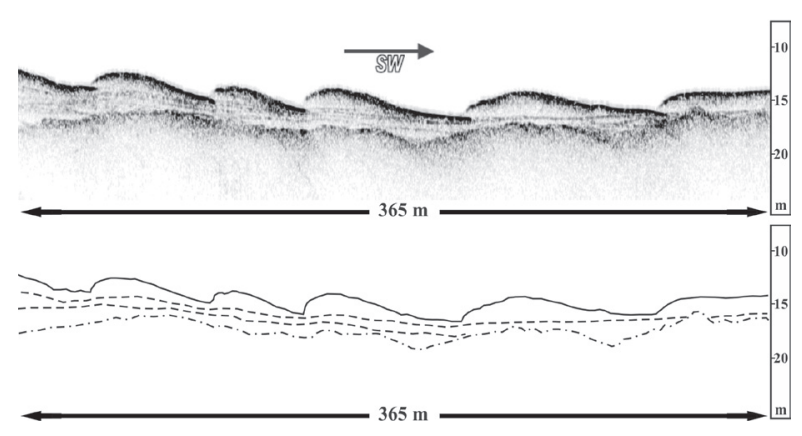

Figure 8 - Example of macro-undulation bedforms with a transversal sand bar migration. Sand bars show plane-parallel layering.

Some profiles, as illustrated in Figure 9, show big clinoforms that highlight the time line, with the longitudinal bedforms migration arranged in macro undulations. The most evident reflectors are interpreted as sedimentation reactivation plans (dashed lines), with a strong seasonal periodicity and the widespread dominance of St and Sp facies type (dotted lines).

In the SW portion of the profile the bar top shows a series of dunes as a response to the flow turbulence. In the NE side of the profile the horizontal bedding is considered as an evidence of predominant laminar flow, which gives origin to the architectural element of laminated sand (LS) type.

The variation on the flow regime and current nature that changes from laminar to turbulent is confirmed by the presence of sections in which a set

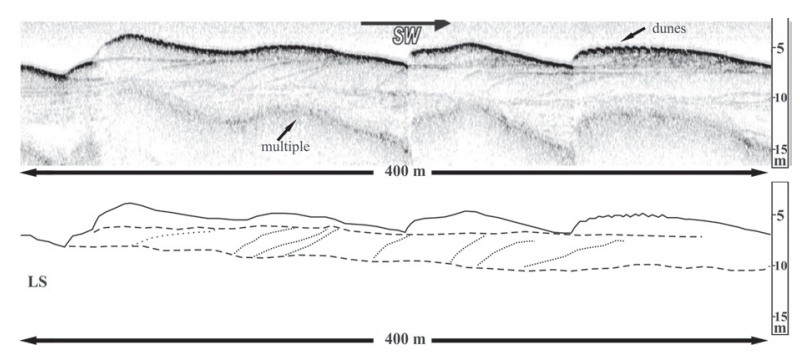

Figure 9 - Lateral channel migration deposits represented by big size clinoforms with deposition of sand and graywakes.

of cut-and-fill bearing facies and channels changes to cross and horizontal strata.

Figure 10 illustrates a case in which a succession of architectural facies of channel type $(\mathrm{CH})$, with the predominance of Se facies at SSW, migrates to architectural elements of longitudinal accretion (DA) towards NNE, with the dominance of sandy St and Sp facies type. The abrupt increase in depth observed in the NNE part of the profile is interpreted as a recent erosional channel.

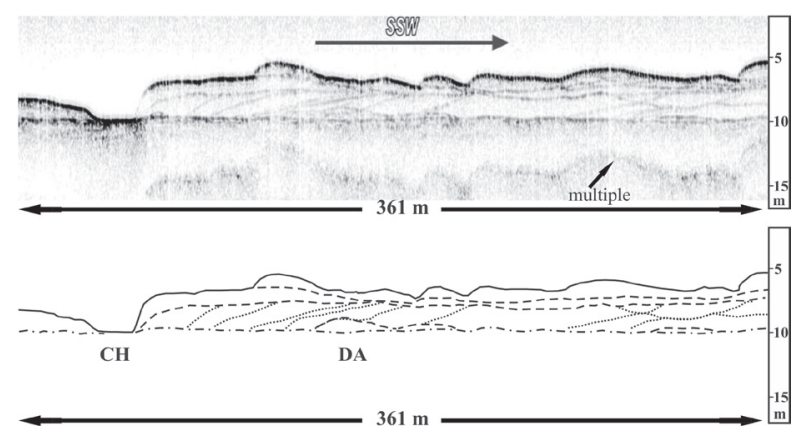

Figure 10 - Region with evident superposition of directional fluxes that give origin to cut-and-fill channels. The texture is of fine sand, with sigmoidal structures, cross stratifications and truncations.

The central part of Figure 11 shows a set of Sh (dashed lines) facies that forms an architectural element of LS type interpreted as a seasonal aggradation of sandy layers. At both NE and SW ends, excellent examples of large cut-and-fill channels (dotted lines), limited by continuous and evident reflectors, are evident.

In areas of minor depth (about $5 \mathrm{~m}$ ) and more uniform currents, the bedforms are composed by a set of transversal bars with varying length and 


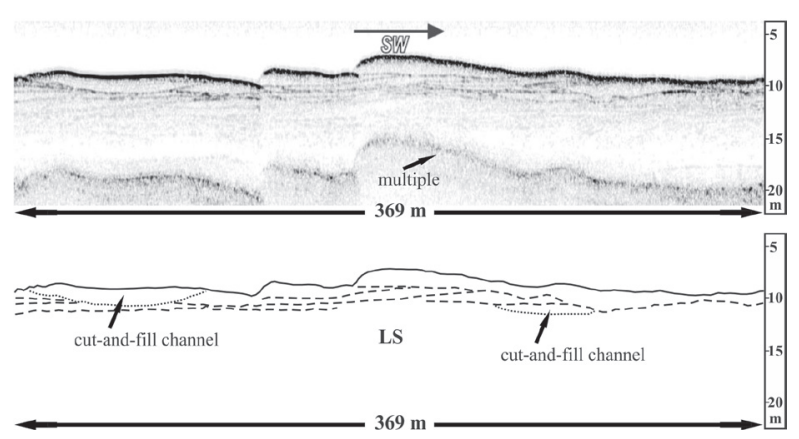

Figure 11 - Sand layer deposits with large cut-and-fill channels at SW and NW section ends.

amplitude of up to $2.5 \mathrm{~m}$. In 3-D, such fea-tures appear as linguoids with a superimposed asymmetrical dune system. Internally such bars show plane-parallel layers with cross and horizontal laminations.

The bedform migration due to the traction flow is considered as the main transport component in such sections where both macroforms and mesoforms migrate downstream.

\section{Transition Environments}

Transition environments are formed in intermediate areas between depositional and by-pass environments and can occur along the longitudinal axis of the river, as well as transversal to the active canal. Two factors control the deposition in these environments: resistance variation of the local basement material and lateral/longitudinal changes of energy and current strength.

Figure 12 presents an example of a transition environment characterized by irregular basement topography (dash-dot line), in which sedimentary deposit thickness varies from sub meter to more than $10 \mathrm{~m}$ downstream. This set forms architectural facies classified as sandy bed (SB) with large dominance of Sh and Sl facies (dashed lines).

Locally, the transition environments are observed downstream of long stretches of rocky bed, and present complex sequences of sandy facies, with dipping reflectors forming sigmoids indicating the balance between flux energy and

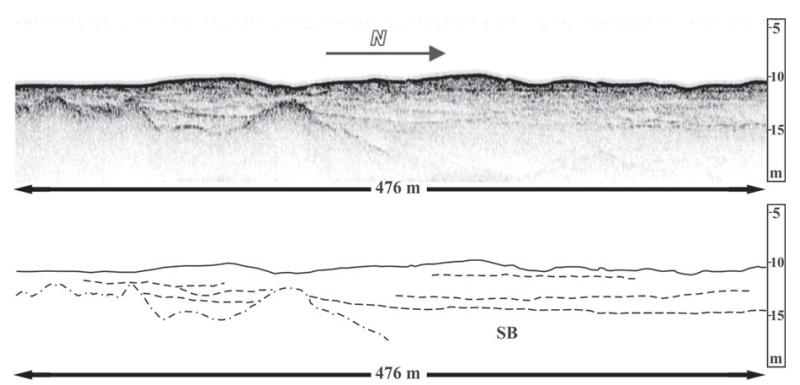

Figure 12 - Sandy sedimentary layers over an acoustic basement characterized by irregular paleo-topography. Horizontally layered or low-angle truncated macroforms are the most common ones.

depth. Basement topography seems to exert some control on depth that shows a tendency to decrease with the increasing of the bedrock depth. Figure 13 shows an example of such transition environment where complex sedimentary facies (dashed lines) follow the outcropping basement (dash-dot line).

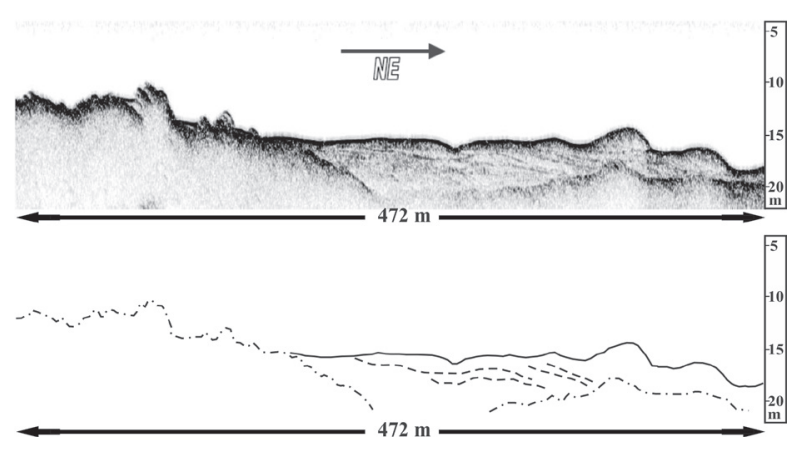

Figure 13 - Transition between outcropping basement and downstream depositional region. The small downstream dipping angle of the layers indicates the action of tangential currents.

FINAL REMARKS

The lower course of the Tocantins River can be classified as anastomosed, due to the presence of mid-channel stable islands and channel deposition dominated by sand, with pelitic deposition being relevant just in the inundation plains.

In particular, along the study area, downstream the city of Tucuruí and the Tucuruí dam, it is observed the progressive plain form evolution from the straight to anastomosed river channel pattern. Comparative analyses of radar images prior to 
the closing of the dam (Brasil 1974) with recent ones (LANDSAT ETM + ) did not show significant changes in the channel pattern. On the other hand, the geophysical survey allowed the identification of erosional, depositional and transitional areas, longitudinally intercalated and transversal to the current river channel.

The presence of such environments seems to be related to the distance to the dam, although the pre-existing waterfall might have played a similar role in trapping the upstream bed load, as suggested by the maintenance of the channel pattern. In the first eighteen kilometers downstream the dam, seismic records show the predominance of bypass environments possibly related to erosional effect of sediment unsaturated flux. Further downstream, the equilibrium in the sedimentary load could have been re-established by the erosion of both bedrock and river margins. Here seismic records show the continuous presence of sandy transversal channel bars.

The methodology used showed that highresolution seismic profilers could be used to study the internal structure of sand bars in alluvial river channels. Collected data show the impressive variety and complexity of architectural elements and internal structure of sandy macroforms.

The results allowed the identification of three main environments linked to channel sedimentation processes: by-pass, transition and deposition environments whose distribution is related to channel dynamics and bedrock topography. The application of the study is manifold once it provides not only an insight into sedimentary structure of alluvial forms and sedimentation history, but also elements demanded to planning eventual engineering works for river navigability.

Furthermore, the results encourage developing further this kind of research, including integration of GPR methods to study emerged alluvial bars and coring to provide information on time-evolution of sedimentation processes.

\section{ACKNOWLEDGMENTS}

The authors thank prof. Augusto Cesar Bittencourt Pires for its review and thoughtful suggestions, and the master student Laiza Oliveira Leal for the support during survey and data processing. The project was financed by Financiadora de Estudos e Projetos (FINEP), Fundo Nacional de Desenvolvimento Científico e Tecnológico (FNDCT), CT - AQUAVIÁRIO - 0135, 2006.

\section{RESUMO}

Até hoje, a maior parte dos estudos de sedimentologia fluvial tem adotado dois principais métodos de investigação: observação direta de trincheiras, faces expostas e testemunhos, ou levantamento geofísico nas regiões emersas ou rasas das barras fluviais. Neste estudo, um perfilador acústico de subfundo foi utilizado para investigar a estratigrafia do baixo curso do Rio Tocantins, na bacia Amazônica, entre a cidade de Tucuruí e a vila de Nazaré dos Patos. O interesse neste trecho do rio reside na possível variação do regime fluvial devido à instalação da barragem da usina hidrelétrica de Tucuruí e à perspectiva de que este rio se torne navegável após a conclusão da construção da eclusa. Os perfis coletados mostram detalhes da variedade e complexidade de elementos arquiteturais e a estrutura interna das macroformas arenosas. Além disso, os resultados permitiram a identificação de três ambientes correlacionados com os processos sedimentares ativos no canal: ambientes de by-pass, transição e deposição, que estão relacionados à dinâmica do canal e topografia do embasamento. A aplicação deste estudo é multíplice, uma vez que fornece informações sobre a estrutura sedimentar das formas aluvionais e histórico de deposição, mostra elementos necessários ao planejamento de eventuais intervenções para a navegabilidade do rio.

Palavras-chave: rio entrelaçado, sedimentologia fluvial, feições arquiteturais, estratigrafia, sísmica de alta resolução. 


\section{REFERENCES}

ANEEL - BANCO DE INFORMAÇÃO DE GERAÇÃO. 2010 http://www.aneel.gov.br/aplicacoes/capacidadebrasil/ GeracaoTipoFase. asp?tipo $=1 \&$ fase $=3$. accessed in jan $/ 2010$.

Baines D, Smith DG, Froese DG and Bauman P. 2002. Electrical resistivity ground imaging (ERGI): A new tool for mapping the lithology and geometry of channel-belts and valley-fills. Sedimentology 49: 441-449.

BARbosa O, RAmos JRA, GOMES FA AND HEMBOLd R. 1966. Geologia estratigráfica, estrutural e econômica da área do Projeto Araguaia. DNPM, Divisão de Geologia e Mineralogia, Rio de Janeiro, Monografia 19: 94. (Unpublished).

BRANDT SA. 2000. Classification of geomorphological effects downstream of dams. CATENA 40(4): 375-401.

BRASIL. 1974. Ministério das Minas e Energia. Projeto RadamBrasil, Folha SC.22 Tocantins; geologia, geomorfologia, solos, vegetação e uso potencial da terra. Rio de Janeiro: Projeto RADAMBRASIL.

Christofoletti A. 1981. Geomorfologia Fluvial. São Paulo, Edgard Blucher Ltda, 313 p.

GuPTA A. 2007. Large Rivers: Geomorphology and Management. J Wiley \& Sons, 689 p.

Hirsch M, BENTLEy L AND Dietrich P. 2008. A Comparison of Electrical Resistivity, Ground Penetrating Radar and Seismic Refraction Results at a River Terrace Site. J Environ Eng Geophys 13(4): 325-333.

Hofmann MH, Hendrix MS, MoOre JN AND Sperazza M. 2006. Late Pleistocene and Holocene depositional history of sediments in Flathead Lake, Montana: Evidence from high-resolution seismic reflection interpretation. Sediment Geol 184(1-2): 111-131.

Hugenholtz CH, MoORMan BJ AND Wolfe SA. 2007. Ground penetrating radar (GPR) imaging of the internal structure of an active parabolic sand dune. In: Stratigraphic Analyses Using Gpr Baker GS and Jol HM (Eds), Geol Soc Am, Special paper 432: 35-45.
LATRUBESSE EM, STEVAUX TJC AND SinHÁ R. 2005. Tropical rivers. Geomorphology 70: 187-206.

LIMA JEFW, SANTOS PMC dOS, CARVALHO N DE O AND SILVA E. 2004. Diagnóstico do fluxo de sedimentos em suspensão na Bacia Araguaia-Tocantins. Planaltina, DF, Embrapa Cerrados, Brasília, DF, ANEEL, ANA, 116 p.

MiALL AD. 1978. Lithofacies types and vertical profile models in braided rivers: a summary. In: Miall AD (Ed), Fluvial Sedimentology, Canadian Society of Petroleum Geologists, Memoirs 5: 605-625.

MiALL AD. 1985. Architectural -element analysis: A new method of facies analysisapplied to fluvial deposits. EarthSci Rev 22: 261-308.

NOVAK B AND BJORCK S. 2002. Late Pleistocene-early Holocene fluvial facies and depositional processes in the Fehmarn Belt, between Germany and Denmark, revealed by high-resolution seismic and lithofacies analysis. Sedimentology 49(3): 451-465.

PotTER PE. 1978. Significance and Origin of Big Rivers. J Geol 86(1): 13-33.

REZENDE NGAM. 1998. Reordenamento estratigráfico do Mesozóico da Bacia do Parnaíba. In: XL Congresso Brasileiro de Geologia, 1998, Belo Horizonte. Anais do XL Congresso Brasileiro de Geologia. Belo Horizonte: Sociedade Brasileira de Geologia.

SAmbrook Smith GH, Ashworth PJ, Best JL, Lunt IA, ORFEO O AND PARSONS DR. 2009. The sedimentology and alluvual arquitecture of a large braid bar, Rio Paraná, Argentina. J Sediment Res 79: 629-642.

SAMBrooK SMith GH, Ashworth PJ, Best JL, WoOdWARD J AND SIMPSON CJ. 2006. The sedimentology and alluvial architecture of the sandy braided South Saskatchewan River, Canada. Sedimentology 53(2): 413-434.

WiLliams GP AND WOLMAN MG. 1984. Downstream effects of dams on alluvial rivers. In: Geological Survey Professional Paper 1286, US Government Printing Office, Washington DC, 83 p. 